\title{
Trace element and stable isotope data from a flowstone in a natural cave of the mining district of SW Sardinia (Italy): evidence for $\mathrm{Zn}^{2+}$-induced aragonite precipitation in comparatively wet climatic conditions
}

\author{
Guglielmo Angelo Caddeo ${ }^{1}$, Jo De Waele ${ }^{2}$, Franco Frau ${ }^{1}$ and L. Bruce Railsback ${ }^{3}$
}

\begin{abstract}
:
Caddeo G.A., De Waele J., Frau F. and Railsback L.B. 2011. Trace element and stable isotope data from a flowstone in a natural cave of the mining district of SW Sardinia (Italy): evidence for $\mathrm{Zn}^{2+}$-induced aragonite precipitation in comparatively wet climatic conditions. International Journal of Speleology, 40 (2), 181-190. Tampa, FL (USA). ISSN 0392-6672. DOI 10.5038/1827-806X.40.2.10

A speleothem from Crovassa Azzurra, a mine cave in SW Sardinia (Italy), has been analysed for mineralogy, minor and trace elements and stable isotopes. It is composed of layers of primary calcite and aragonite, with a region of secondary calcite. The primary carbonate is strikingly rich in $\mathrm{Zn}$ and $\mathrm{Pb}$, presumably as the result of transport in solution from overlying $\mathrm{Pb}-\mathrm{Zn}$ deposits. Immediately below the transition between calcite and aragonite, concentrations of $\mathrm{Zn}, \mathrm{Cd}$ and $\mathrm{P}$ increase. At the transition between aragonite and $\mathrm{Pb}$-rich aragonite, concentrations of $\mathrm{Pb}$ and $\mathrm{P}$ increase. Stable isotopes do not indicate an evolution toward drier periods for these two transitions, conversely to what is normally observed in calcite-aragonite speleothems. On the contrary the combined observation of increase in $\mathrm{P}$ and metals derived from oxidation of sulphides and the variation of isotopic composition of aragonite and calcite suggests that in this mine cave aragonite was deposited with increasing flowrate and thus more humid conditions. In addition, the effect of $\mathrm{Zn}^{2+}$ or $\mathrm{Pb}^{2+}$ in inhibiting precipitation of calcite appears to have been more important than that of $\mathrm{Mg}^{2+}$.
\end{abstract}

Keywords: mine cave; speleothems; trace elements; stable isotopes; mineralogy; calcite; aragonite; kinetics; environmental reconstruction

Received 15 March 2011; Revised 23 April 2011; Accepted 15 May 2011

\section{INTRODUCTION}

Many natural caves in the Lower Cambrian limestones and dolostones of SW Sardinia (Italy) have been discovered during mine excavations in several $\mathrm{Pb}-\mathrm{Zn}$ sulphide deposits. These "mine caves" host a wide variety of speleothems, both from a morphological and mineralogical point of view. Besides the rather uncommon cave minerals such as hemimorphite, hydrozincite, barite and cerussite, most of the speleothems are composed of aragonite and calcite. Another anomaly of the region is that aragonite is found here, in the stability field of calcite, in much larger quantities than in normal karstic settings.

Many authors agree that the principal cause of metastable precipitation of aragonite in cave environments is related to the presence of $\mathrm{Mg}^{2+}$ in the percolating fluids (Hill \& Forti, 1997 and references

\footnotetext{
${ }^{1}$ Dipartimento di Scienze della Terra, Via Trentino 51 - 09127 Via Trentino 51 - 09127 Cagliari, Italy (g.caddeo@unica.it; frauf@unica.it).

${ }^{2}$ Dipartimento di Scienze della Terra e Geologico-Ambientali, Via Zamboni 67 - 40126 Bologna, Italy (jo.dewaele@unibo.it).

${ }^{3}$ Department of Geology, University of Georgia, Athens, Georgia, 30602-2501 USA (rlsbk@gly.uga.edu).
}

therein). The inhibiting effect of $\mathrm{Mg}^{2+}$ on the deposition of calcite has been confirmed by many experimental studies (Murray, 1954; Curl, 1962; Roques, 1965; Bischoff, 1968; Berner, 1975; Morse, 1983; Mucci, 1986; Fernandez-Diaz et al., 1996; Davis et al., 2000; De Choudens-Sanchez \& Gonzalez, 2009). On the other hand, many studies have shown that the growth rate of aragonite is not influenced by the presence of $\mathrm{Mg}$ in solution, since this element is not incorporated in the aragonite structure (Berner, 1975; Mucci \& Morse, 1983; Jimenez-Lopez et al., 2004).

Studies carried out in karst areas have confirmed the role of the $\mathrm{Mg}^{2+}$ ion as inhibitor of calcite precipitation (Cabrol, 1978; Gonzales \& Lohmann, 1988; Bar-Matthews et al., 1991; Railsback et al., 1994). Besides, in the majority of cases, the calcitearagonite transitions in speleothems appear to be related to changes in environmental and climatic conditions towards aridity, since the reduction of water flow feeding the speleothem favors the increase in $\mathrm{Mg} / \mathrm{Ca}$ (Cabrol, 1978; Gonzales \& Lohmann, 1988; Bar-Matthews et al., 1991; Railsback et al., 1994; Frisia et al., 2002; Pagliara et al., 2010). $\mathrm{Mg}^{2+}$, in fact, tends to concentrate in residual solutions, because its partition coefficient is less than 1 with respect to both aragonite and calcite. 
These findings have a general validity, since $\mathrm{Mg}^{2+}$ is by far the most abundant solute in karst waters that is able to inhibit the growth rate of calcite in caves. However, many other solutes are supposed to inhibit precipitation of calcite (Cabrol, 1978; Meyer, 1984), even though the details of such inhibition are not well described and understood. Thus, in some particular cases like the mine caves of Iglesiente (SW Sardinia, Italy), where other cations such as $\mathrm{Pb}^{2+}$ and $\mathrm{Zn}^{2+}$ are present in significant concentrations, the precipitation of aragonite might also be related to other factors inhibiting calcite precipitation.

If the increase in concentration of these metals in the water inside mine caves has an important role in the genesis of aragonite, the appearance of this mineral phase would be related to environmental processes that favor the increase of these solutes in the solutions. These processes, however, can be very different from those that cause an increase in $\mathrm{Mg}^{2+}$.

The study of the chemical variation along profiles perpendicular to the growth bands of calcite towards aragonite can be useful in understanding the possible inhibiting role of minor elements on the precipitation of both minerals. Variation in concentration of a chemical constituent in the solid phase, in absence of relevant variations in partition coefficient, reflects change in that constituent's concentration in the original fluid. At the transition from calcite to aragonite, concentrations in the solid commonly change because of the difference of the partition coefficients for any given element with respect to the two minerals. However, extrapolating that trend into the following aragonite layer allows evaluation of the extent to which that constituent was more concentrated in solutions from which aragonite was formed, relative to the earlier solution from which calcite precipitated.
To investigate the possible role played by different solutes in the genesis of aragonite and to understand the environmental significance of calcite-aragonite banding in caves associated with sulphide mines, a flowstone from the Crovassa Azzurra in the San Giovanni Mine (Sardinia, Italy) has been sampled and studied.

\section{STUDY AREA}

Crovassa Azzurra is a small natural cave intercepted by the Peloggio mine tunnel at $218 \mathrm{~m}$ asl in the San Giovanni Mine, in SW Sardinia (Fig. 1). These underground works have exploited a very rich $\mathrm{Pb}-\mathrm{Zn}$ deposit of the Mississippi Valley Type since the middle of the XIX ${ }^{\text {th }}$ century until the late 1980 s (Bechstadt \& Boni, 1996). The host rock consists of limestones and dolostones of Lower Cambrian age.

The mountain in which the mine was cut hosts over 50 mine caves with no known natural entrance and thus accessible only via the mine voids. The most famous of these is the Santa Barbara cave that, like many other caves of this area, is of hypogenic origin (Pagliara et al., 2010). These caves often contain rather uncommon cave minerals such as hydrozincite, hemimorphite and barite. Many have widespread aragonite speleothems in the form of helictites, but there are also aragonitic flowstones.

The climate of the area is of the Mediterranean type, with hot and dry summers and relatively wet winters and autumns. Average air temperature in the caves of Mount San Giovanni is around $15.5^{\circ} \mathrm{C}$ (Chiesi, 2005).

The Crovassa Azzurra cave consists of two underground rooms connected by a small and narrow shaft, which is dissected by the mine tunnel. Most of the walls in both rooms are composed of a bluish flowstone, composed of an alternation of white-grey-

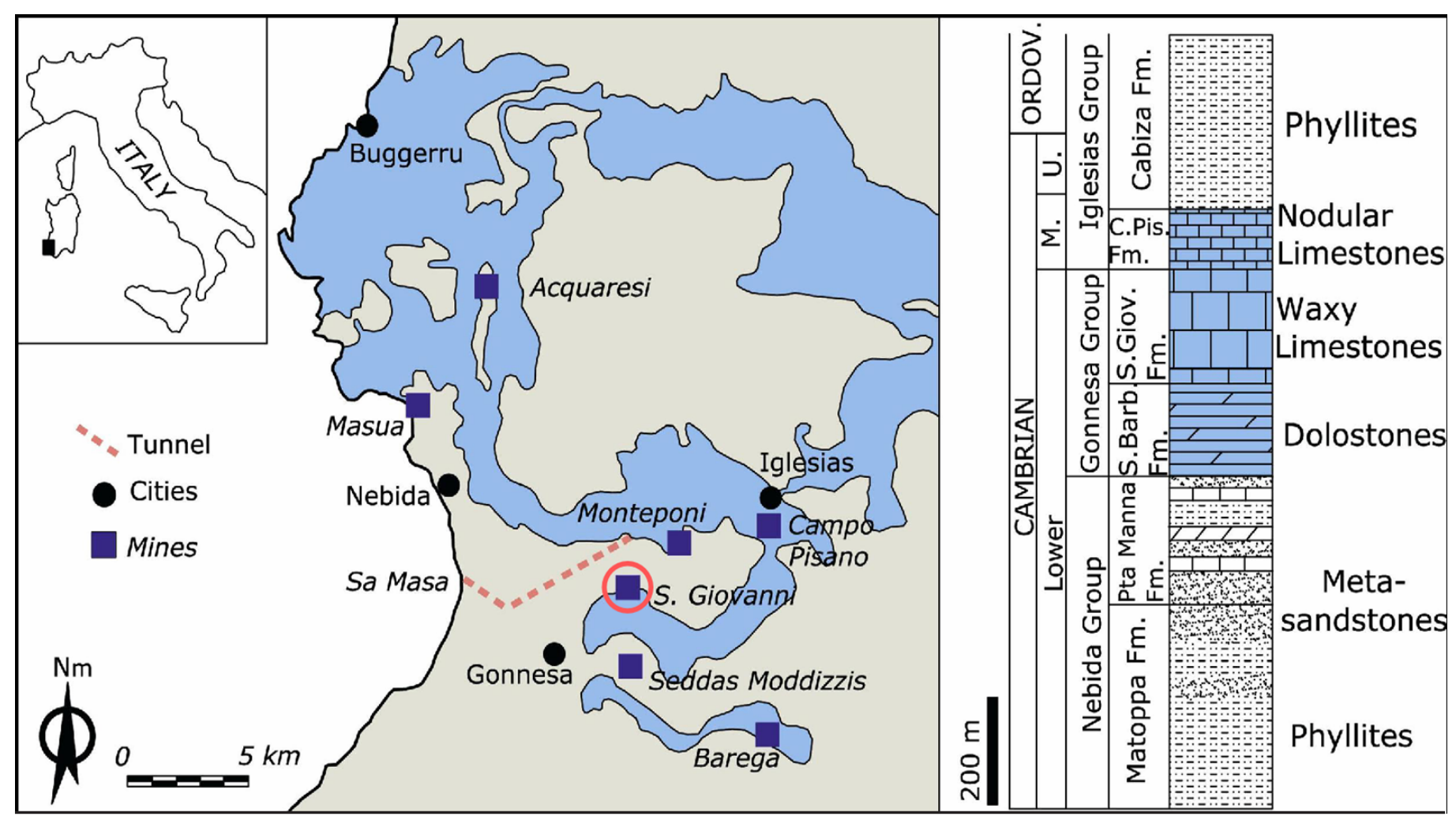

Fig. 1. Location in southwestern Sardinia of Crovassa Azzurra, San Giovanni Mine and the Iglesias mining district. 
bluish calcite and bluish aragonite layers. The lower room shows clear evidence of a standing water level, with calcite dogtooth spar at the bottom. The sample SGV9 described and studied in this paper derives from the flowstone in the upper room.The sample SVG9 was taken from a flowstone in the Crovassa Azzurra in the San Giovanni Mine, close to the city of Iglesias in SW Sardinia. Two thin sections (transparent and polished) were prepared for the study via polarising optical microscopy and laser ablation. Samples for $\mathrm{X}$-ray diffraction and stable isotope $(\mathrm{C}$ and $\mathrm{O})$ analyses were obtained by drilling at several points using a dental drill.

The mineral phases have been determined using a Panalytical X'Pert Pro X-ray diffractometer $(\mathrm{Cu}$ $\mathrm{K}_{\mathrm{a}}$ radiation, operating at $40 \mathrm{~mA}$ and $40 \mathrm{kV}$ ) at the Department of Earth Sciences of the University of Cagliari (Sardinia, Italy).

Carbon and oxygen stable isotope analyses were performed by a method modified from McCrea (1950). Samples weighing roughly $5 \mathrm{mg}$ were reacted under vacuum in $100 \%$ phosphoric acid at $50^{\circ} \mathrm{C}$. The resulting $\mathrm{CO}_{2}$ was extracted on a conventional vacuum line and analyzed on Finnigan MAT Delta E and MAT 252 mass spectrometers at the Department of Geology of the University of Georgia (Athens, USA). Laboratory standards were prepared and analyzed with each batch of samples. These standards have been calibrated to NBS- $19\left(\delta^{13} \mathrm{C}=+1.95, \delta^{18} \mathrm{O}=-2.2 \%\right.$ o relative to VPDB) and NBS-18 $\left(\delta^{13} \mathrm{C}=-5.0\right.$ and $\delta^{18} \mathrm{O}$ $=-23.0 \%$ o relative to $\mathrm{VPDB})$. Sample isotopic results are normalized to the lab standards using a twopoint scale, so that all $\delta^{13} \mathrm{C}$ and $\delta^{18} \mathrm{O}$ values herein are reported relative to VPDB. The 2-sigma error of the combined extraction and analysis is $0.04 \%$ or for $\delta^{13} \mathrm{C}$ and $0.05 \%$ o for $\delta^{18} \mathrm{O}$.

The minor and trace elements have been studied along the banding of polished sections using Laser Ablation Inductively Coupled Plasma Mass Spectrometry (LA-ICP-MS). This instrument at the Department of Earth Sciences in Cagliari consists of a Perkin Elmer Elan DRC ICP-MS coupled with a New Wave Research Nd:YAG Laser, working at a wavelength of $213 \mathrm{~nm}$. All analyses have been acquired at a frequency of $10 \mathrm{~Hz}$ and a spot size of 50 $\mu \mathrm{m}$. Inside the ablation chamber, He has been used as a carrier gas, mixed with Ar as makeup gas, before entering the ICP system.

In this work the data on eight elements are considered: $\mathrm{Mg}, \mathrm{P}, \mathrm{Cu}, \mathrm{Zn}, \mathrm{Sr}, \mathrm{Cd}, \mathrm{Ba}$ and $\mathrm{Pb}$. The calibration strategy was achieved using the NIST 612 glass as external standard and ${ }^{43} \mathrm{Ca}$ as internal standard. For each spot analysis the weight concentrations of the internal standard were previously determined in the Department of Geology of the University of Georgia (Athens, USA) by a wavelength dispersive system of a JEOL JXA 8600 electron microprobe. Data elaboration, regarding the concentrations of the different elements for each spot analysis, has been performed using the software GLITTER (Van Achterbergh et al., 2001). Only the obtained values of concentration over the Minimum Detection Limit, which was always less than $7 \mathrm{ppm}$ for $\mathrm{P}$ and less than $1 \mathrm{ppm}$ for $\mathrm{Mg}, \mathrm{Zn}, \mathrm{Pb}, \mathrm{Ba}, \mathrm{Cd}$, $\mathrm{Sr}$ and $\mathrm{Cu}$, was considered. Quality control of the

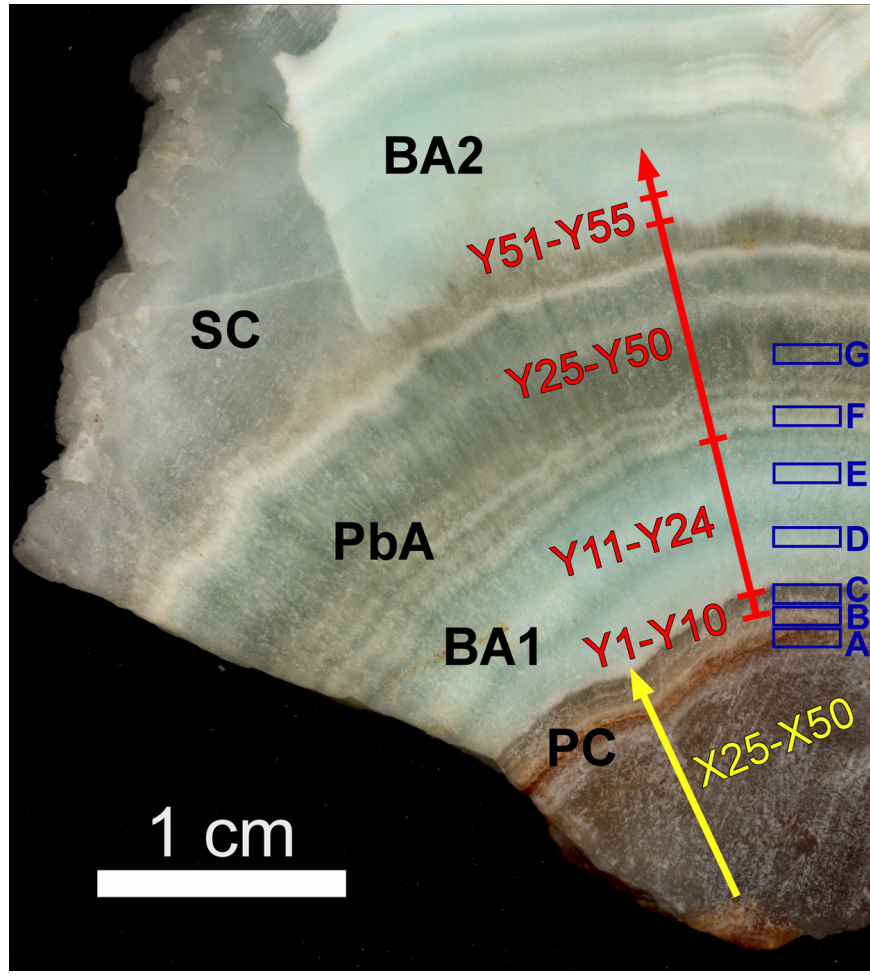

Fig. 2. Sample SGV9 with the location of the traverses $X$ and $Y$ and subsamples PC (primary calcite), BA1 (blue aragonite 1), $\mathrm{PbA}$ (Pb-rich aragonite), BA2 (blue aragonite 2) and SC (secondary calcite). The blue rectangles indicate the sampling points for stable isotope analyses.

data was monitored during each analytical session by repeated analyses of a natural standard glass (BCR-2). This standard indicated a precision (RSD\%) within $10 \%$ for all the investigated elements and better than $3 \%$ for $\mathrm{Mg}$, $\mathrm{Ba}$ and $\mathrm{Sr}$.

The polished section has also been studied with a Scanning Electron Microscope (SEM) Quanta 200 at the Centro Grandi Strumenti of the University of Cagliari. This SEM is coupled with an Energy Dispersive System (EDS) EDAX with which some spectra have been acquired relative to some specific analyses. The identification of the peaks and the semi-quantitative analyses has been carried out for each spectrum using the elaboration software GENESIS. The observations have been done using electron backscattering and working at low vacuum conditions.

\section{Mineralogical composition}

Analysis via $\mathrm{X}$-ray diffraction shows that the sample consists, from bottom to top, of brown and grey layered calcite and then a wide interval of layers of blue, green and white aragonite (Fig. 2). Laterally equivalent to the uppermost layers of aragonite is a region of light and less distinctly layered calcite.

The aragonite can be divided into three sub-layers on the basis of colours and $\mathrm{Pb}$ content as determined by SEM-EDX. A middle green aragonite sub-layer $(\mathrm{PbA})$ having some white horizons is much richer in $\mathrm{Pb}$ than lower (BA1) and upper (BA2) blue aragonite sub-layers. In backscatter-SEM images (Fig. 3a) the transition from the lower to the middle sub-layer of 
aragonite is very evident because of a sharp increase in brightness. Backscatter-SEM images and EDX microanalysis also showed the presence of some cerussite $\left(\mathrm{PbCO}_{3}\right)$ crystals having a size between 1 and $50 \mu \mathrm{m}$ (Fig. 3b). The cerussite crystals are enclosed in the white horizons of the $\mathrm{PbA}$ aragonite sub-layer, where maximum $\mathrm{Pb}$ concentrations in the aragonite matrix are also observed.

In the upper part of the sample, an irregular region of light calcite designated SC is present in an area laterally equivalent to the uppermost aragonite. Petrographic observation of this calcite reveals some aragonite relicts and an equant fabric. The SC calcite is therefore interpreted to have replaced some portion of blue BA2 aragonite and to have a secondary origin (Fig. 4a).

Beneath the aragonite, at the base of the sample, a layered region of brown and grey calcite is found and is designated $\mathrm{PbC}$. This calcite has a parallelcolumnar fabric typical of spelean calcite and thus is interpreted to be primary (Figs. $4 b$ and $4 c$ ).

\section{Minor and Trace Elements} Introduction

Analyses with LA-ICP-MS reveal the presence of $\mathrm{Mg}, \mathrm{Zn}, \mathrm{Cu}, \mathrm{Sr}, \mathrm{Ba}, \mathrm{Pb}$, and $\mathrm{P}$ as minor and trace elements both in calcite and aragonite. The concentration of these elements is variable along traverses perpendicular to the flowstone layers, and these geochemical variations can provide insight into the mineralogical and environmental changes. The

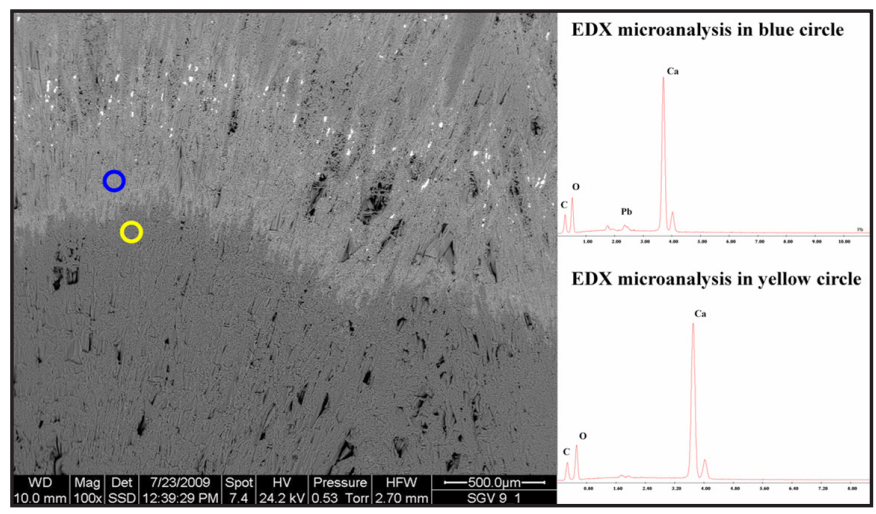

Fig. 3a. Backscatter SEM image, showing a zone of passage between aragonite poor in $\mathrm{Pb}$ below (yellow circle, BA1) and aragonite rich in $\mathrm{Pb}$ above (blue circle, $\mathrm{PbA}$ ).

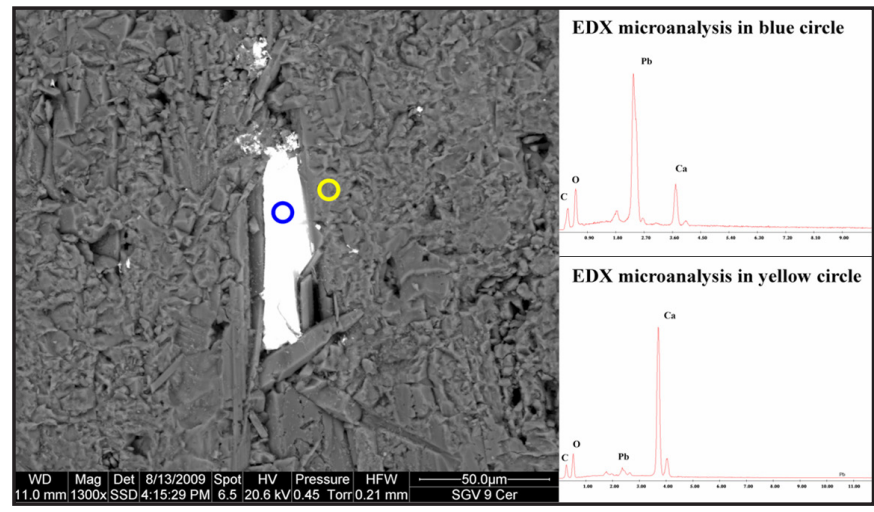

Fig. 3b. Backscatter SEM image, showing a cerussite crystal (blue circle) enclosed in aragonite rich in $\mathrm{Pb}$ (yellow circle). most notable general observation is that $\mathrm{Zn}$ and $\mathrm{Pb}$ concentrations in the flowstone are exceptionally high. For example, in some analyses the concentration by weight of $\mathrm{Zn}^{2+}$ in calcite exceeds that of $\mathrm{Mg}^{2+}$, which is typically by far the most abundant minor cation in spelean calcite. Similarly, in some analyses the concentration of $\mathrm{Pb}^{2+}$ in aragonite exceeds that of $\mathrm{Sr}^{2+}$, which is typically the most abundant minor cation in spelean aragonite.

Figure 2 indicates the position of two traverses, designated $\mathrm{X}$ and $\mathrm{Y}$, that were carried out on sample SGV9. Traverse $X$ crosses the entire layer of primary calcite PC along the growth direction, from the substrate on which it starts up to layer BA1 (not included). This first traverse is composed of 43 sampling points, with a distance between points of $250 \mu \mathrm{m}$. Traverse Y crosses the upper part of the primary calcite layer and continues along the following aragonite layer BA2. This traverse can be subdivided into 4 intervals. The first interval, from Y1 to Y10, contains 10 analyses in the terminal part of layer $\mathrm{PC}$ with distance between points of $100 \mathrm{\mu m}$. Intervals Y11-Y24, Y25-Y50, and Y51-Y55 have sampling points $350 \mu \mathrm{m}$ apart and are related to layers $\mathrm{BA} 1, \mathrm{PbA}$, and $\mathrm{BA} 2$ respectively. Analyses were also done on the secondary calcite (SC) to allow comparison with the primary calcite (PC) (Fig. 5).

\section{Secondary calcite}

Secondary calcite (SC) shows lower $\mathrm{Mg}$ concentration that the primary calcite (PC). This is probably due to the low $\mathrm{Mg}$ content of the precursor aragonite and perhaps also to the slow rate of secondary precipitation, and thus decreased partition coefficient of $\mathrm{Mg}^{2+}$ (Railsback, 1999), during the transformation of aragonite to calcite. On the other hand, Sr concentrations are much higher in secondary calcite, probably because they were inherited from the precursor aragonite (Fig. 5). The same holds true, but less strikingly, for Ba (Fig. 5), and presumably for the same reason. Conversely, $\mathrm{Zn}$ content is greater in primary calcite but probably only because this element was present in lower concentration in the aragonite precursor to the secondary calcite.

\section{Primary calcite: traverse $X$}

The results along traverse $\mathrm{X}$ are reported in Fig. 6. In the interval from $\mathrm{X} 1$ to $\mathrm{X} 40$, the concentrations of $\mathrm{Zn}$ are always less than 1.3 mole \% in $\mathrm{ZnCO}_{3}$. From X41 to X43 the concentration of $\mathrm{Zn}$ increases significantly and, in points X41 and X43, is twice that of the mean value of the first 40 analyses. $\mathrm{Zn}$ concentration reaches a maximum value of 3 mole $\%$ in the final point immediately before entering the aragonite layer (Fig. 6a). X42, instead, has a Zn concentration similar to that of the first 40 points, but it contains the greatest concentration of $\mathrm{Mg}$ (over 5 mole \%). In general, however, concentrations in $\mathrm{Mg}$ never exceed 4 mole \%, and in the last point (X43), where $\mathrm{Zn}$ concentration is greatest, $\mathrm{Mg}$ concentration is less than 3.5 mole \%. In the final part of the traverse, where the variations in $\mathrm{Zn}$ are greater, $\mathrm{Mg}$ and $\mathrm{Zn}$ are negatively correlated (Fig. 7). 
In some points along traverse $X$, large concentrations of $\mathrm{Pb}$ are visible $(\mathrm{X} 4, \mathrm{X} 15, \mathrm{X} 18, \mathrm{X} 21$, $\mathrm{X} 24$, and X27), generally accompanied by large concentrations of $\mathrm{Zn}$. This becomes clear also from Figure $6 \mathrm{~b}$, where a correlation between $\mathrm{P}$ and $\mathrm{Pb}$ is also visible, while $\mathrm{Mg}$ seems to be negatively correlated. Maxima in $\mathrm{Pb}$ also correspond to maxima in $\mathrm{P}$ (X1, $\mathrm{X} 4, \mathrm{X} 7, \mathrm{X} 11, \mathrm{X} 15, \mathrm{X} 18, \mathrm{X} 21, \mathrm{X} 24, \mathrm{X} 34, \mathrm{X} 41$, and $\mathrm{X}$ 43). Also $\mathrm{Cd}$ increases in the final part, resulting in covariance with $\mathrm{Pb}, \mathrm{P}$, and $\mathrm{Zn}$. In general it appears that $\mathrm{P}$ and the metals derived from the oxidation of sulphides $(\mathrm{Zn}, \mathrm{Pb}$, and $\mathrm{Cd})$ have a similar behavior, and show a negative correlation with $\mathrm{Mg}$.

\section{Upper primary calcite and aragonite: traverse $Y$}

The results of traverse $\mathrm{Y}$ are shown in Fig. 8. The transition from calcite to aragonite is shown by the interruption of the lines. The behavior of the elements in the first part of this traverse, in the upper part of the primary calcite, confirms the observations done on the terminal part of traverse $\mathrm{X}$. Here again the concentration of $\mathrm{Zn}$ increases, reaching its maximum value in the uppermost calcite layer, very close to the beginning of aragonite. Also the maximum $\mathrm{Mg}$ concentration is reached at $\mathrm{Y} 8$, just below the transition to aragonite, with a slight decrease in the final part (Y9 and Y10) (Fig. 8a). Also, the covariance of $\mathrm{P}$ with the metals derived from oxidation of sulphides $(\mathrm{Pb}, \mathrm{Zn}$, and $\mathrm{Cd})$ and the negative correlation between these elements and $\mathrm{Mg}$ are confirmed (Fig. 8b).

Further along traverse $\mathrm{Y}$, variations in minor and trace elements in the transition from calcite to aragonite are readily explained by the change in mineralogy. At the transition to aragonite, concentrations in $\mathrm{Mg}, \mathrm{Zn}$, and $\mathrm{Cu}$ decrease, because the relatively small cations of these bivalent elements have smaller distribution coefficients in aragonite than in calcite. Nevertheless, $\mathrm{Zn}$ and $\mathrm{Cu}$ show minor decreases with respect to $\mathrm{Mg}$, staying at concentrations between 720 and 328 ppm and 179 and $82 \mathrm{ppm}$, respectively. The concentration of ions with greater radius instead increases, since these are more readily incorporated into aragonite than into calcite. Among these ions are $\mathrm{Sr}^{2+}$, which increases at this mineral transition from 60 to 1360 ppm; $\mathrm{Ba}^{2+}$, which increases from 68 to $505 \mathrm{ppm}$; and $\mathrm{Pb}^{2+}$, which increases from 138 to 427 ppm. $\mathrm{P}$ and $\mathrm{Pb}$ persist in covarying in the aragonite layer as they did in the calcite layer. For instance, the rapid increase in $\mathrm{P}$ is accompanied by a rapid increase in $\mathrm{Pb}$ at the transition from the underlying aragonite layer BA1 to the plumbiferous aragonite above $(\mathrm{PbA})$, at points $\mathrm{Y} 24$ and Y25.

\section{Carbon and Oxygen stable isotopes}

Stable isotope analyses have been carried out along the growth axis (orthogonal to the layers) and are reported in Figure 9. Of the 7 analyses, three (A, $\mathrm{B}$, and $\mathrm{C}$ ) were in primary calcite, two (D and $\mathrm{E}$ ) in aragonite without exceptional $\mathrm{Pb}$ concentrations and the remaining two ( $F$ and $G$ ) in the plumbiferous aragonite. Each analysis sampled an area much larger than the laser ablation spots, because they have been obtained by a dental drill taking 10-15 mg of powder, and thus can include multiple LA analysis points.
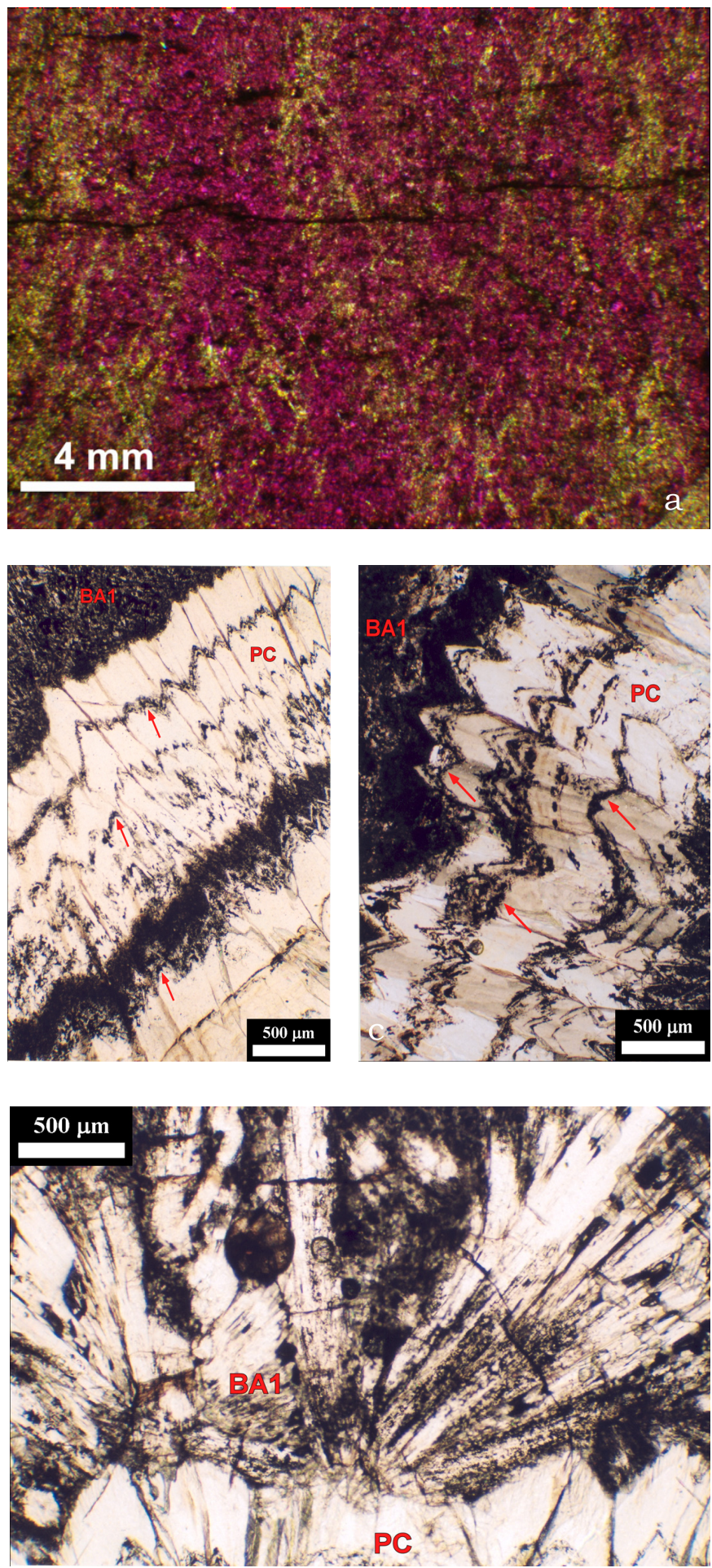

Fig. 4a. Relics of aragonite (yellow zones) in secondary calcite (SC). Photomicrograph taken in cross- polarized light with a gypsum plate

Fig. 4b. Primary calcite (PC) below blue aragonite (BA1). Columnar calcite aggregate contains many impurity bands (red arrows) that mark the former growth front. Photomicrograph taken in planepolarized light.

Fig. 4c. Primary calcite (PC) below blue aragonite (BA1). Columnar calcite aggregate contains many impurity bands (red arrows) that mark the former growth front. Photomicrograph taken in planepolarized light.

Fig. 4d. Blue aragonite overgrowth (BA1) on primary calcite layer (PC). Photomicrograph taken in plane- polarized light. 
The three analyses in calcite reveal a small but consistent increase in $\delta^{18} \mathrm{O}$. Also $\delta^{13} \mathrm{C}$ increases slightly from $\mathrm{B}$ to $\mathrm{C}$ but decreases between $\mathrm{A}$ and $B$. The increase in $\delta^{13} \mathrm{C}$ is much greater from $\mathrm{C}$ to $\mathrm{D}$, corresponding to the passage from primary calcite to aragonite. In normal conditions, however, $\delta^{13} \mathrm{C}$ of aragonite is greater than that of calcite by $1.68 \%$, for values close to $-10 \%$ o (Romanek et al., 1992). Also $\delta^{18} \mathrm{O}$, in normal conditions, suffers a greater fractionation in aragonite with respect to calcite. At a temperature of $15^{\circ} \mathrm{C}$ this difference is $0.8 \%$ (Kim et al., 2007). To be able to compare the isotopic fractionation of the waters giving rise to calcite and aragonite, assuming there have not been sensible temperature variations, it is thus necessary to make a correction. The dashed line in Figure 7 shows these corrected values with respect to the measured ones (full lines). From these corrected values it becomes evident that the mean isotopic composition of aragonite shows lower values in $\delta^{18} \mathrm{O}$ and $\delta^{13} \mathrm{C}$ with respect to those obtained from calcite, and that this is especially true for the $\mathrm{Pb}$-rich aragonite of isotope samples $\mathrm{F}$ and $\mathrm{G}$.

\section{DISCUSSION}

Change from calcite to aragonite in speleothems is often explained by environmental changes towards aridity, and one controlling factor seems to be the $\mathrm{Mg} / \mathrm{Ca}$ ratio in the depositing fluids (Railsback et al., 1994; Frisia et al., 2002; Baker et al., 2008). The increase in this ratio can in fact be connected to a decrease in recharge of the speleothem depositing waters. The more residual a water becomes, the more prior precipitation has occurred and the greater the $\mathrm{Mg} / \mathrm{Ca}$ ratio becomes, since the repartition coefficient of $\mathrm{Mg}$ with respect to calcite is $<1$.

In the flowstone from Crovassa Azzurra, stable isotope analyses of the primary calcite and overlying aragonite do not seem to indicate a change from more humid to arid conditions or reductions of flowrate at the passage between calcite and aragonite. On the contrary, the preliminary isotope data indicate the possibility that aragonite might have deposited in slightly more humid conditions than calcite.
To make a correct palaeoclimate interpretation of these data, from a general point of view at these mid latitudes, presently characterised by semi-arid climate, an enrichment in heavy isotopes along the growth layers of stalagmites or flowstones is normally considered a sign of increase in aridity (Bar-Matthews et al., 1999). An important factor that makes the $\delta^{13} \mathrm{C}$ in speleothems increase during less humid periods is the prolonged degassing to which cave waters are subjected (Frisia et al., 2002). If a seeping water, along a certain distance, reaches more rapidly the surface of a flowstone or a stalagmite, it will also have had less time to release $\mathrm{CO}_{2}$ to the cave atmosphere, resulting in an enrichment in the heavy isotope ${ }^{13} \mathrm{C}$.

With regard to oxygen, the increase in isotopic ratio ${ }^{18} \mathrm{O} /{ }^{16} \mathrm{O}$ in the feeding waters is generally associated to a shift to more arid climate, since it is in these conditions that evaporation increases significantly. Evaporation can be extremely efficient, especially during the hot and dry seasons (Bar-Matthews et al., 1999; Denniston et al., 1999). Evaporation can even be more important inside caves during the dry season, because of longer air-water interaction during the pathway of the solution towards the place of deposition. The decrease in $\delta^{18} \mathrm{O}$ in the transition from calcite to aragonite does not support the hypothesis of the aragonite genesis in an increasingly arid climate. If we also assume that increases in $\mathrm{Mg} / \mathrm{Ca}$ ratios are related to decreases in flowrate, the stable isotope data also contradict the hypothesis that aragonite formation was related to the inhibiting effect of $\mathrm{Mg}^{2+}$ on calcite formation. The calcite-aragonite transition in the Crovassa Azzurra flowstone is thus not readily explained by changing saturation state and $\mathrm{Mg} /$ $\mathrm{Ca}$ ratios, and other controlling factors have to be considered.

\section{The $\mathbf{Z n - P b}$ hypothesis}

A possible explanation for the precipitation of aragonite during an apparent increase of flowrate might be the inhibiting effect of dissolved $\mathrm{Zn}^{2+}$ and/ or $\mathrm{Pb}^{2+}$ on calcite growth. Meyer (1984) showed that small concentrations of dissolved $\mathrm{Zn}^{2+}$ and $\mathrm{Pb}^{2+}$

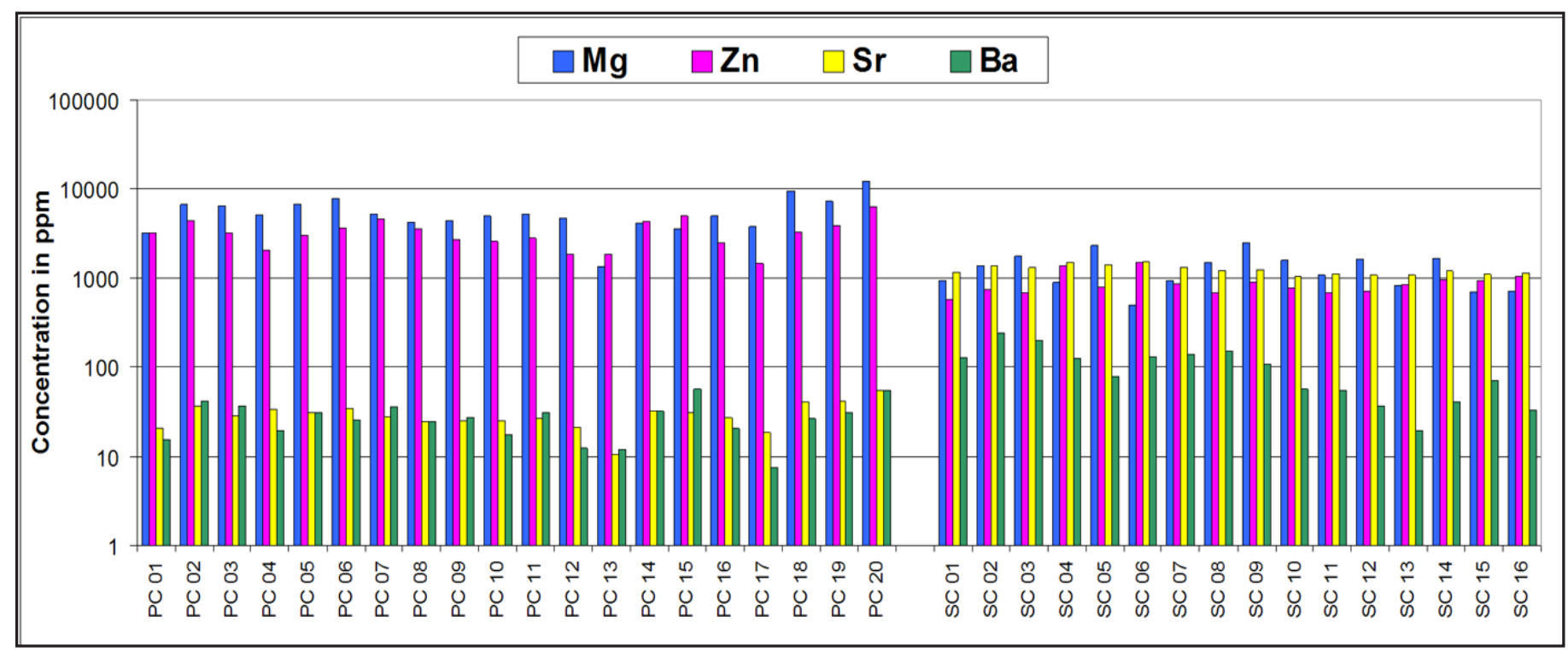

Fig. 5. Comparison of minor element composition in primary (PC, left) and secondary calcite (SC, right). 


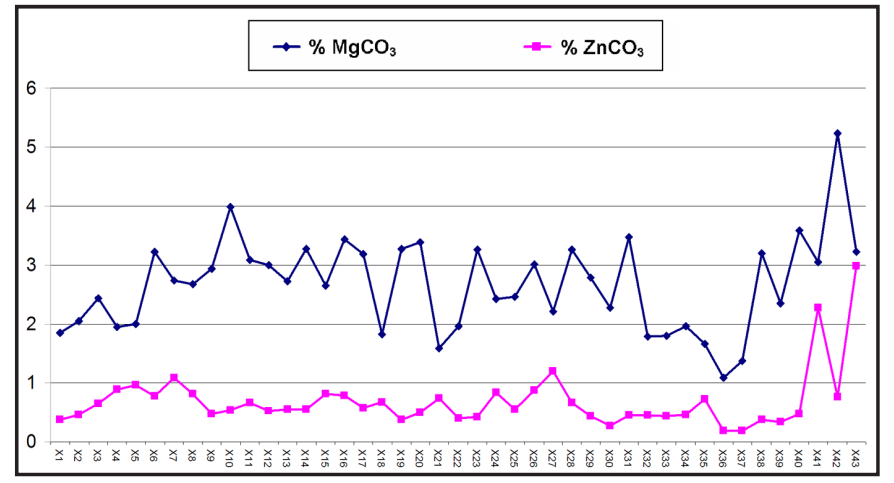

Fig. 6a. Molar percentages of $\mathrm{Mg}$ and $\mathrm{Zn}$ along traverse $\mathrm{X}$.

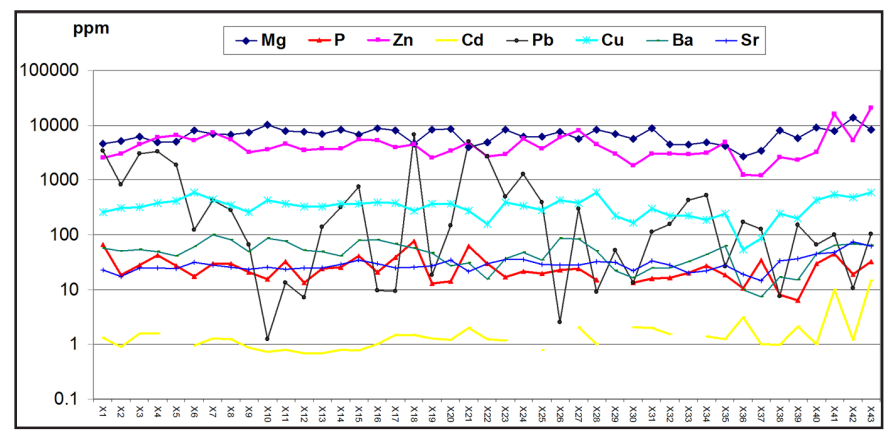

Fig. 6b. Comparison in logarithmic scale of concentrations of various minor and trace elements along traverse $\mathrm{X}$.

diminish the rate of growth of calcite from solution. Calculations by Meyer (1984) showed that, even at small concentrations, these ions could occupy all of the possible cation sites at steps on the surface of a growing calcite crystal. More recently, Rouff et al. (2005) and Elzinga et al. (2006) likewise concluded that adsorption of $\mathrm{Pb}^{2+}, \mathrm{Zn}^{2+}$, and $\mathrm{Cu}^{2+}$ on calcite surfaces can limit mineral-solution exchange and thus inhibit calcite growth. Such ions are relevant because they are relatively soluble in circumneutral oxidizing solutions, whereas $\mathrm{Fe}^{2+}$, for example, is readily oxidized to $\mathrm{Fe}^{3+}$ that then precipitates as a hydrous oxide of some sort and thus, like other trivalent ions (e.g., $\mathrm{Al}^{3+}$ and $\mathrm{Sc}^{3+}$ ), is less relevant to solution-calcite interaction. $\mathrm{Zn}^{2+}$ and $\mathrm{Pb}^{2+}$ are especially relevant to the Crovassa Azzurra cave flowstone because they could readily enter solution as the result of oxidative weathering of the sulphides in the mine above the cave.

During the precipitation of calcite, the behavior of $\mathrm{Pb}^{2+}$ should be analogous to that of $\mathrm{Mg}^{2+}$, in that both have partition coefficients in calcite much less than 1 . Thus, precipitation of calcite should increase the $\mathrm{Pb} /$ $\mathrm{Ca}$ ratio of the precipitating solution, as much as it causes an increase of the $\mathrm{Mg} / \mathrm{Ca}$ ratio. In contrast, the behavior of $\mathrm{Zn}^{2+}$ should be the opposite inasmuch the partition coefficient for $\mathrm{Zn}^{2+}$ in calcite is $>1$ because the cation size of $\mathrm{Zn}^{2+}$ provides a nearly ideal fit for the calcite cation site (Railsback, 1999). Thus precipitation of calcite preferentially removes $\mathrm{Zn}^{2+}$ from the solution and leads to a smaller $\mathrm{Zn} / \mathrm{Ca}$ ratio in the residual solution. This may in part account for the inverse correlation of $\mathrm{Mg}$ and $\mathrm{Zn}$ in the last analyses of Traverse X (Fig. 7). The observed increase in the $\mathrm{Zn} / \mathrm{Ca}$ ratio of calcite (Fig. 6), and the inferred increase in the $\mathrm{Zn} / \mathrm{Ca}$ ratio in the solution, may reflect a major input of $\mathrm{Zn}$ at its source linked to more humid periods. This would be compatible with the observed isotopic signal.

\section{Evidence of aragonite deposition during wetter conditions}

Evidence of a humid period during precipitation of aragonite in the Crovassa Azzurra flowstone may come from the LA-ICP-MS data regarding phosphorus. Huang et al. (2001) have demonstrated that P in speleothems is mainly present as phosphate, and that its concentration increases systematically in response to more humid periods. P, according to these authors, can thus be taken as an indicator of flow rate changes at the depositing speleothem. The covariance between $\mathrm{P}$ and the metals related to the oxidation of sulphides $(\mathrm{Pb}, \mathrm{Zn}$, and $\mathrm{Cd})$ suggests that oxidative weathering and the transport in solution of the weathering products is more efficient during wet periods, when these metals increase their concentrations in the percolating waters (Fig. 6). Cidu \& Frau (2009), in a study of surface waters in mine areas of Sardinia, have demonstrated that the concentration of metals, such as $\mathrm{Pb}, \mathrm{Zn}$, and $\mathrm{Cd}$, tends to increase in conditions of major flow. This behavior might also be valid for a karst system.

Further evidence for evolution toward wetter conditions during deposition of the Crovassa Azzurra flowstone comes from the stable isotope data. Both corrected $\delta^{13} \mathrm{C}$ and $\delta^{18} \mathrm{O}$ decreased during aragonite deposition from their corresponding levels during earlier calcite deposition (Fig. 9). Variation in both of these parameters can result from many environmental changes, but the most fundamental control on $\delta^{13} \mathrm{C}$ of spelean calcite is the abundance of overlying vegetation (e.g., Hesterberg \& Siegenthaler, 1991; Baldini et al., 2005), with lower values corresponding to more vegetation and thus, in most cases, wetter conditions. Likewise, the major controls on $\delta^{18} \mathrm{O}$ of spelean calcite commonly include amount effects of rainfall (McDermott, 2004) and evaporation of soil water (Bar-Matthews et al., 1996), and in both cases smaller $\delta^{18} \mathrm{O}$ values correspond to wetter conditions. Thus, the $\mathrm{C}$ and $\mathrm{O}$ stable isotope data reinforce the

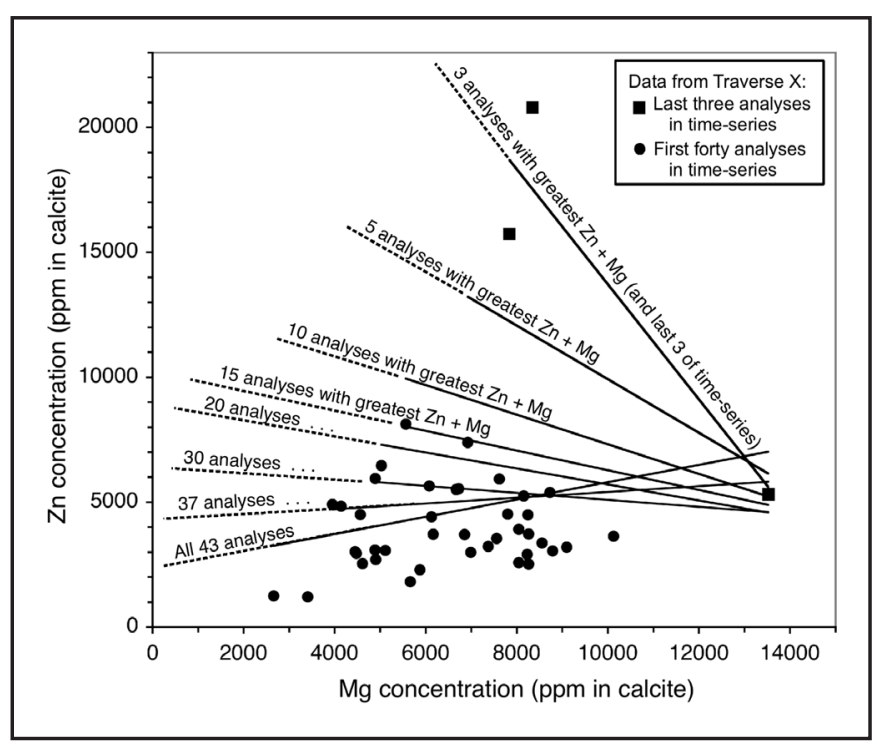

Fig. 7. Plot of $\mathrm{Zn}$ and $\mathrm{Mg}$ concentrations in calcite along Traverse $X$. The various lines for linear regression show that, within the entire set of data, $\mathrm{Zn}$ and $\mathrm{Mg}$ are positively correlated, but among the analyses richer in $\mathrm{Zn}$ and $\mathrm{Mg}$ there is an inverse correlation. 


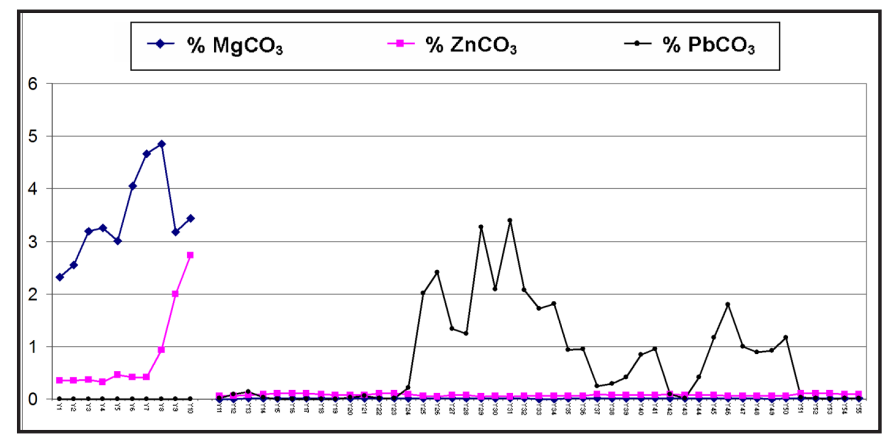

Fig. 8a. Molar percentages of $\mathrm{Mg}, \mathrm{Zn}$, and $\mathrm{Pb}$ along traverse $\mathrm{Y}$.

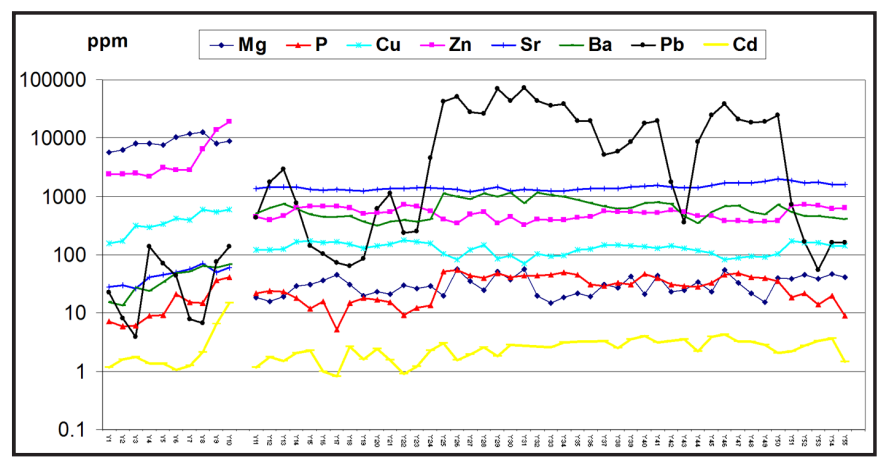

Fig. 8b. Comparison in logarithmic scale of concentrations of various minor and trace elements along traverse $Y$. The transition between calcite and aragonite corresponds to the interruption of lines.

$\mathrm{P}$ concentration data in suggesting wetter conditions during the precipitation of aragonite, and in particular the $\mathrm{Pb}$-rich aragonite, of the Crovassa Azzurra flowstone.

Origin of the Crovassa Azzurra flowstone aragonite

The considerations above combine to present a strong argument that precipitation of aragonite in the Crovassa Azzurra flowstone was not driven by $\mathrm{Mg}^{2+}$ inhibition of calcite or by more arid conditions. Instead, multiple lines of evidence suggest that inhibition of precipitation of calcite by $\mathrm{Zn}^{2+}$ and perhaps $\mathrm{Pb}^{2+}$ during wetter conditions allowed precipitation of aragonite. With regard to climate, both the increasing $P$ concentration in calcite underlying aragonite and the lower values of "corrected" $\delta^{13} \mathrm{C}$ and $\delta^{18} \mathrm{O}$ in aragonite relative to calcite suggest a trend to wetter rather than drier conditions during aragonite deposition. The increase in $\mathrm{Zn}$ concentration observed in calcite underlying aragonite and the large $\mathrm{Pb}$ concentrations additionally suggest greater oxidation of sulphides such as sphalerite and galena in waters descending from the overlying $\mathrm{Pb}-\mathrm{Zn}$ ore deposits to the cave itself. This argument is supported by the greater concentration of $\mathrm{Pb}, \mathrm{Zn}$, and $\mathrm{Cd}$ during greater flow of surface waters in the region (Cidu \& Frau, 2009).

With regard to inhibiting effects of various cations, the decrease in $\mathrm{Mg}$ concentration immediately below the transition to aragonite (Figs. 6 and 8) suggests that inhibition of calcite precipitation by dissolved $\mathrm{Mg}^{2+}$ was not the controlling factor in triggering deposition of aragonite. Instead, the known capacity of $\mathrm{Zn}^{2+}$ and $\mathrm{Pb}^{2+}$ to inhibit precipitation of calcite (Meyer, 1984), combined with observed increases in $\mathrm{Zn}$ concentration in the calcite immediately below the transition to aragonite, suggest that these metal cations, and especially $\mathrm{Zn}^{2+}$, were the significant inhibiting agents. This is not surprising in light of the large $\mathrm{Zn}$ concentrations in the Crovassa Azzurra flowstone and Meyer's (1984) observation that $\mathrm{Zn}^{2+}$ and $\mathrm{Pb}^{2+}$ are much more effective inhibitors of calcite precipitation than is $\mathrm{Mg}^{2+}$.

In addition to the cation-driven inhibitions of calcite precipitation considered above, some anions can also inhibit precipitation of calcite. For example, $\mathrm{SO}_{4}{ }^{2-}$ can inhibit precipitation of both calcite and aragonite, with a greater inhibition of calcite (Walter, 1986). However, SEM-EDX analyses yielded no evidence of $\mathrm{S}$ within the flowstone, suggesting that $\mathrm{SO}_{4}{ }^{2-}$ was of little significance to precipitation of the flowstone. $\mathrm{PO}_{4}^{3-}$ can also inhibit precipitation of both calcite and aragonite, but it causes a greater inhibition of aragonite (Walter, 1986; Burton \& Walter, 1990). Thus, the presence of $\mathrm{PO}_{4}^{3-}$ in Crovassa Azzurra waters, as inferred from flowstone composition, cannot explain inhibition of calcite coeval with precipitation of aragonite. These thoughts combine to suggest that cations like $\mathrm{Zn}^{2+}$ and $\mathrm{Pb}^{2+}$ were more likely inhibiting agents than the dissolved anions.

The paragraphs above focus on changes within the latest calcite, or differences in isotopic composition between the calcite and aragonite, as evidence of the changes that induced precipitation of aragonite rather than calcite. In addition, a good example of the effectiveness of this unusual model of aragonite deposition comes from stable isotope sample $\mathrm{F}$ and the coeval LA-ICP-MS data from analyses 25 to 30 of transect $\mathrm{Y}$. In this interval of aragonite, corrected values of $\delta^{13} \mathrm{C}$ and $\delta^{18} \mathrm{O}$ reach their smallest values, and $\mathrm{P}$ and $\mathrm{Pb}$ concentrations reach their greatest values. This interval thus epitomizes the characteristics of the aragonite, suggesting deposition in wet, rather than dry, conditions.

\section{CONCLUSION}

Multiple lines of evidence combine to suggest that aragonite in a flowstone from Crovassa Azzurra below the San Giovanni Mine in SW Sardinia (Italy) has formed not because of $\mathrm{Mg}^{2+}$-inhibition of calcite and/

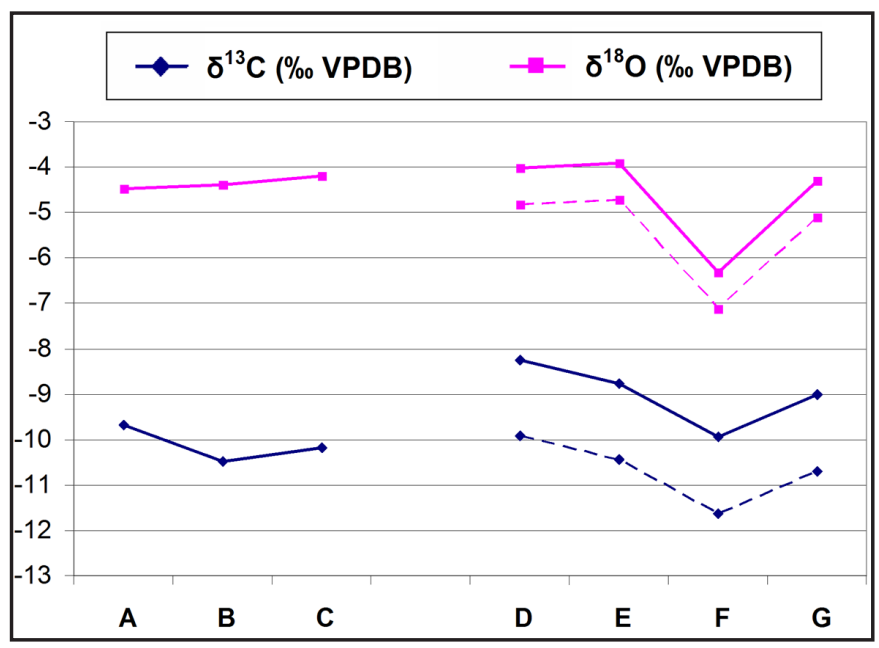

Fig. 9. Variation of isotopic composition. The dashed line represents the hypothetical isotope composition of calcite deposited instead of aragonite. 
or dry conditions but instead because of inhibition of calcite precipitation by $\mathrm{Zn}^{2+}$, and perhaps $\mathrm{Pb}^{2+}$, in wetter conditions than those under which calcite previously formed. This interpretation is unusual, because the factors most commonly cited as favoring spelean deposition of aragonite rather than calcite are presence of $\mathrm{Mg}^{2+}$ in drip water, higher temperature, and drier conditions (e.g., Railsback et al., 1994). This unusual interpretation comes from a speleothem exceptional for its large concentrations of $\mathrm{Zn}^{2+}$ and $\mathrm{Pb}^{2+}$, where $\mathrm{Zn}^{2+}$ concentrations by weight in calcite are locally greater than those of $\mathrm{Mg}^{2+}$, and where $\mathrm{Pb}^{2+}$ concentrations in aragonite are locally greater than those of $\mathrm{Sr}^{2+}$. These unusual aragonite and calcite chemistries, and presumably the unusual chemistries of the waters that precipitated the flowstone, are the result of the presence of sulphide mineral deposits in the overlying bedrock. Thus, the findings of this study are not generally applicable to all occurrences of aragonite. However, they may be applicable in other regions where chemistries of karst waters are anomalous, particularly as the result of input from weathering of sulphides. Furthermore, this study provides evidence that many factors can control the polymorphism of $\mathrm{CaCO}_{3}$ in spelean deposits. These factors should be taken into account when obtaining paleoclimatic information from speleothems.

\section{ACKNOWLEDGEMENTS}

This research was funded by Università degli Studi di Cagliari (Italy), as part of a $\mathrm{PhD}$ program. The research was produced in collaboration with the Department of Geology of the University of Georgia (USA). The authors acknowledge the Centro Grandi Strumenti of Università di Cagliari for granting access to the use of SEM/EDX.

We also would like to thank Julie Cox, Chris Fleisher and Francesca Podda for their assistance in the laboratory respectively of Stable Isotopes, SEM/ WDS and LA-ICP-MS.

Finally, this manuscript was improved by constructive comments from two anonymous reviewers and Giovanni Zanchetta of the Dipartimento di Scienze della Terra of Università di Pisa.

\section{REFERENCES}

Baker A., Smith C.L., Jex C., Fairchild I.J., Genty D. \& Fuller L., 2008 - Annually Laminated Speleothems: a Review. International Journal of Speleology, 37(3): 193-206.

Baldini J.U.L., McDermott F., Baker A., Baldini L.M., Mattey D.P. \& Railsback L.B., 2005 - Biomass effects on stalagmite growth and isotope ratios: A 20th century analogue from Wiltshire, England. Earth and Planetary Science Letters, 240: 486494.

Bar-Matthews M., Ayalon A., Kaufman A. \& Wasserburg G.J., 1999 - The Eastern Mediterranean paleoclimate as a reflection of regional events: Soreq cave, Israel. Earth and Planetary Science Letters, 166(1-2): 85-95.
Bar-Matthews M. Ayalon, A. Matthews A., Sass E., and Halicz L. 1996 - Carbon and oxygen isotope study of the active water-carbonate system in a karstic Mediterranean cave: Implications for paleoclimate research in semiarid regions: Geochimica et Cosmochimica Acta, 60: 337-347.

Bar-Matthews M., Matthews A. \& Ayalon A., 1991 Environmental Controls of Speleothem Mineralogy in a Karstic Dolomitic Terrain (Soreq Cave, Israel). Journal of Geology, 99(2): 189-207.

Bechstadt T. \& Boni M., 1996 - Sedimentological, stratigraphical and ore deposits field guide of the autochtonous Cambro-Ordovician of Southwestern Sardinia. Memorie descrittive della Carta Geologica d'Italia, 48: 1-390.

Berner R.A., 1975 - The role of magnesium in the crystal growth of calcite and aragonite from sea water. Geochimica et Cosmochimica Acta, 39: 489-504.

Bischoff J.L., 1968 - Kinetics of calcite nucleation: magnesium ion inhibition and ionic strength catalysis. Journal of Geophysical Research, 73: 3315-3322.

Burton E.A. \& Walter L.M., 1990 - The role of $p H$ in phosphate inhibition of calcite and aragonite precipitation rates in seawater. Geochimica et Cosmochimica Acta, 54: 797-808.

Cabrol P., 1978 - Contribution à l'étude du concrétionnement carbonaté des grottes du Sud de la France: morphologie, génèse, diagénèse. Mémoires du Centre d'études et de recherches géologiques et hydrogéologiques, 12: 1-275.

Chiesi M., 2005 - Il pre-monitoraggio dei parametri ambientali della Grotta di Santa Barbara (Miniera di San Giovanni, Iglesias). In: De Waele J. \& Naseddu A. (Eds.) - Le Grotte di Miniera: tra economia mineraria ed economia turistica. Memorie dell'Istituto Italiano di Speleologia, 17, Bologna: 23-34

Cidu R. \& Frau F., 2009 - Distribution of trace elements in filtered and non filtered aqueous fractions: insights from rivers and streams of Sardinia (Italy). Applied Geochemistry, 24(4): 611-623.

Curl R.L., 1962 - The aragonite-calcite problem. NSS Bulletin, 24: 57-73.

Davis K.J., Dove P.M. \& De Yoreo J.J., 2000 - The role of $\mathrm{Mg}^{2+}$ as an impurity in calcite growth. Science, 290: 1134-1137.

De Choudens-Sanchez V. \& Gonzalez L.A., 2009 Calcite and aragonite precipitation under controlled instantaneous supersaturation: elucidating the role of $\mathrm{CaCO}_{3}$ saturation state and $\mathrm{Mg} / \mathrm{Ca}$ ratio on Calcium Carbonate polymorphism. Journal of Sedimentary Research, 79(5-6): 363-376.

Denniston R.F., Gonzalez L.A., Baker R.G., Asmerom Y., Reagan M.K., Edwards R.L. \& Alexander E.C., 1999 - Speleothem evidence for Holocene fluctuations of the prairie-forest ecotone, northcentral USA. Holocene, 9(6): 671-676.

Elzinga E. J., Rouff A.A. \& Reeder R. J., 2006 - The long term fate of $\mathrm{Cu}^{2+}, \mathrm{Zn}^{2+}$, and $\mathrm{Pb}^{2+}$ adsorption complexes at the calcite surface; an X-ray absorption spectroscopy study. Geochimica et Cosmochimica Acta, 70: 2715-2725. 
Fernandez-Diaz L., Putnis A., Prieto M. \& Putnis C.V., 1996 - The role of magnesium in the crystallization of calcite and aragonite in a porous medium. Journal of Sedimentary Research, 66(3): 482491.

Frisia S., Borsato A., Fairchild I.J. \& McDermott F., 2002 - Aragonite-calcite relationships in speleothems (Grotte de Clamouse, France): environment, fabrics and carbonate geochemistry. Journal of Sedimentary Research, 72: 687-699.

Gonzales L.A. \& Lohmann K.C., 1988 - Controls on mineralogy and composition of spelean carbonates. Carlsbad Caverns, New Mexico. In: James N.P. \& Choquette P.W. (Eds.) - Paleokarst. SpringerVerlag, New York: 81-101

Hesterberg R. \& Siegenthaler U., 1991 - Production and stable isotope composition of $\mathrm{CO}_{2}$ in a soil near Bern. Switzerland. Tellus, 43B: 197-205.

Hill C.A. \& Forti P., 1997 - Cave minerals of the World. National Speleological Society, Huntsville, Alabama, USA, 463 p.

Huang H.M., Fairchild I.J., Borsato A., Frisia S., Cassidy N.J., McDermott F. \& Hawkesworth C.J., 2001 - Seasonal variations in Sr, Mg and $P$ in modern speleothems (Grotta di Ernesto, Italy). Chemical Geology, 175(3-4): 429-448.

Jimenez-Lopez C., Romanek C.S., Huertas F.J., Ohmoto H. \& Caballero E., 2004 - Oxygen isotope fractionation in synthetic magnesian calcite. Geochimica et Cosmochimica Acta, 68(16): $3367-$ 3377.

Kim S.-T., O'Neil J. R., Hillaire-Marcel C. \& Mucci A., 2007 - Oxygen isotope fractionation between synthetic aragonite and water: Influence of temperature and $\mathrm{Mg}^{2+}$ concentration. Geochimica et Cosmochimica Acta, 71: 4704-4715.

McCrea J.M., 1950 - On the isotopic chemistry of carbonates and a paleotemperature scale. Journal of Chemical Physics, 18: 849-857.

Meyer H.G., 1984 - The influence of impurities on the growth rate of calcite. Journal of Crystal Growth, 66: 639-646.

McDermott F., 2004 - Palaeo-climate reconstruction from stable isotope variations in speleothems: a review: Quaternary Science Reviews, 23: 901-918.

Morse J.W., 1983 - The kinetics of calcium carbonate dissolution and precipitation. In: Reeder R.J. (Ed.) - Carbonates: mineralogy and chemistry. Mineralogical Society of America, Reviews in Mineralogy: 227-264
Mucci A., 1986 - Growth kinetics and composition of magnesian calcite overgrowths precipitated from seawater: quantitative influence of orthophosphate ions. Geochimica et Cosmochimica Acta, 50: 2255-2265.

Mucci A. \& Morse J.W., 1983 - The incorporation of $\mathrm{Mg}^{2+}$ and $\mathrm{Sr}^{2+}$ into calcite overgrowths: influence of growth rate and solution composition. Geochimica et Cosmochimica Acta, 47: 217-233.

Murray J.W., 1954 - The deposition of calcite and aragonite in caves. Journal of Geology, 62: 481492.

Pagliara A., De Waele J., Forti P., Galli E. \& Rossi A., 2010 - Speleothems and speleogenesis of the hypogenic Santa Barbara cave system (South-West Sardinia, Italy). Acta Carsologica, 39(3): 551-564.

Railsback L.B., 1999 - Patterns in the compositions, properties, and geochemistry of carbonate minerals. Carbonates and Evaporites, 14 (1): 1-20.

Railsback L.B., Brook G.A., Chen J., Kalin R. \& Fleisher C.J., 1994 - Environmental Controls on the Petrology of a Late Holocene Speleothem from Botswana with Annual Layers of Aragonite and Calcite. Journal of Sedimentary Research Section a-Sedimentary Petrology and Processes, 64(1): 147-155.

Romanek C.S., Grossman E.L. \& Morse J.W., 1992 - Carbon Isotopic Fractionation in Synthetic Aragonite and Calcite - Effects of Temperature and Precipitation Rate. Geochimica et Cosmochimica Acta, 56(1): 419-430.

Roques H., 1965 - Sur la genèse des formations aragonitiques naturelles. Annales de Spéléologie, 20: $47-54$.

Rouff A.A., Elzinga E. J., Reeder R. J. \& Fisher N. S., 2005 - The influence of $\mathrm{pH}$ on the kinetics, reversibility and mechanisms of $\mathrm{Pb}(\mathrm{II})$ sorption at the calcite-water interface. Geochimica et Cosmochimica Acta, 69: 5173-5186.

Van Achterbergh E., Ryan C.G., Jackson S.E. \& Griffin W.L., 2001 - Data reduction software for LA-ICPMS. In: Sylvester P. (Ed.) - Laser-ablation-ICPMS in the earth sciences: principles and applications. Mineralogical Association of Canada: 239-243.

Walter L.M., 1986 - Relative efficiency of carbonate dissolution and precipitation during diagenesis: a progress report on the role of solution chemistry. In: Gautier D.L. (Ed.) - Roles of Organic Matter in Sediment Diagenesis. Society of Economic Paleontologists and Mineralogists Special Publication 38: 1-11. 